\title{
PELAYANAN KARDIOLOGI DI INDONESIA DAN PROBLEMATIKA MEDIKO-LEGAL
}

\author{
Erwin G. Kristanto \\ Bagian Kedokteran Forensik dan Medikolegal Fakultas Kedokteran \\ Universitas Sam Ratulangi Manado \\ Email: gk_erwin@yahoo.com
}

\begin{abstract}
This article shows the extent of needs in health services especially cardiology clinics in Indonesia, medico-legal risks that may come up, dan principled steps to decrease the risks. The evolving changes in health regulation have also been discussed, along with cases that occured in Indonesia. Lack or withholding information, failure in diagnosis and therapy, and lack of caution were problems that must be addressed properly. Recommendations that come with this article are expected to benefit the cardiologists in health service with lower risks of legal sue.
\end{abstract}

Keywords: Cardiology, medico-legal, health services

\begin{abstract}
Abstrak: Artikel ini menunjukkan kebutuhan layanan kesehatan khususnya di bidang Kardiologi di Indonesia, risiko medikolegal yang dapat timbul dari pelayanan tersebut, dan langkah prinsip untuk mengurangi risiko tersebut. Bergeraknya tata aturan dalam pelayanan kesehatan dan dampaknya bagi pelayanan kesehatan di bidang Kardiologi juga menjadi titik bahasan, dengan merujuk pada kasus yang terjadi di Indonesia. Penyampaian informasi yang kurang baik, kegagalan diagnosis dan terapi, kurangnya kehati-hatian, merupakan hal yang harus menjadi perhatian dalam praktik kedokteran khususnya di bidang Kardiologi. Rekomendasi yang dipaparkan dalam tulisan ini diharapkan juga mampu membawa manfaat bagi pelayanan di bidang Kardiologi yang lebih baik dengan risiko medikolegal yang lebih kecil.
\end{abstract}

Kata kunci: Kardiologi, medikolegal, pelayanan kesehatan

Pelayanan kedokteran di bidang kardiologi merupakan salah satu pelayanan kedokteran yang paling banyak dibutuhkan di Indonesia, terutama di rumah sakit dengan pelayanan subspesialistik. Hingga tahun 2013, kurang lebih 244.775.797 penduduk Indonesia dilayani oleh 550 dokter spesialis dan spesialis konsultan jantung dan pembuluh darah, serta 350 dokter peserta Program Pendidikan Dokter Spesialis (PPDS) yang tersebar di 12 pusat pendidikan di seluruh Indonesia. ${ }^{1,2}$

Penyakit jantung dan pembuluh darah merupakan salah satu penyakit yang paling banyak diderita oleh populasi di Indonesia. Sejak tahun 2007, Standar Pelayanan
Minimal Upaya Pengendalian Penyakit Jantung dan Pembuluh Darah telah disusun oleh Sub-Direktorat Pengendalian Jantung dan Pembuluh Darah, Direktorat Pengendalian Penyakit Tidak Menular, Dirjen Pengendalian Penyakit dan Lingkungan, Departemen Kesehatan Republik Indonesia bekerjasama dengan Pusat Manajemen Kesehatan FKUGM karena disadari pentingnya penanganan penyakit jantung dan pembuluh darah. $^{2}$

Pelayanan penanganan penyakit jantung dan pembuluh darah di Indonesia saat ini diwajibkan untuk disediakan oleh setiap pemerintah daerah, dengan indikator angka kematian akibat penyakit jantung 
koroner kurang dari 100 per 100.000 penduduk dan angka kematian akibat stroke kurang dari 60 per 100.000 penduduk. Kewajiban penanganan penyakit jantung dan pembuluh darah ini menciptakan kebutuhan tenaga dokter spesialis dan spesialis konsultan dengan bidang kompentensi terkait menjadi besar. Berdampingan dengan bidang spesialisasi lain yang terkait penanganan penyakit jantung dan pembuluh darah, maka terbuka lapangan pengabdian bagi dokter spesialis jantung dan pembuluh darah di setiap provinsi di Indonesia. $^{2}$

Peningkatan luasnya lapangan tugas dan pengabdian ini, tentu saja beriringan dengan peningkatan risiko terjadinya problem medikolegal dalam praktik. Laporan dugaan kelalaian medik yang ditujukan pada dokter spesialis jantung dan pembuluh darah pada rentang 1997 hingga 2004 ialah 3,03\% dari total kasus laporan dugaan kelalaian medik yang dilaporkan ke tingkat nasional. ${ }^{3}$ Mengingat peluang terjadinya risiko medikolegal baik pada dokter maupun pasien akibat suatu tindakan medik maka komunikasi antara pasien dan dokter harus selalu diutamakan dan dipelihara agar tidak terjadi baik kesalahpahaman maupun sengketa medik antara dokter dan pasien maupun keluarganya. ${ }^{4}$

\section{PROBLEMATIKA MEDIKOLEGAL}

\section{Penyampaian informasi}

Sebagian kasus sengketa medik dimulai dengan tidak efektifnya jalinan komunikasi antara tenaga kesehatan dan pasien atau keluarganya. Seorang pasien berharap saat dokter memberikan informasi kepadanya, ia akan mengetahui diagnosis dan kondisi kesehatannya saat ini, apa yang akan dilakukan padanya saat ini, apa yang dapat pasien harapkan dari pemeriksaan dan terapi yang akan direncanakan dokter, kelebihan dan kekurangan modalitas yang akan digunakan dokter, serta alternatif yang dimilikinya. ${ }^{4}$

Penyampaian informasi yang adekuat dan dapat dipahami merupakan hak pasien dan keluarganya yang harus diberikan oleh tenaga kesehatan. Dokter harus menghindari anggapan bahwa pasien dan keluarganya sudah tahu tentang kondisi kesehatannya, walau pasien tersebut merupakan sejawat atau tenaga kesehatan, atau pernah berobat ke pemberi pelayanan kesehatan lain. Pasien juga harus diberi kesempatan yang cukup untuk memberi respons terhadap penyampaian informasi tersebut (prinsip autonomy). ${ }^{4}$

Penahanan atau disembunyikannya sebagian informasi dengan sengaja melalui berbagai dalih dapat menyebabkan pasien dan keluarganya merasa dibohongi atau ditipu. Dokter harus mengingat bahwa perubahan paradigma hubungan dokter pasien saat ini, menuntut dokter untuk dapat lebih jujur dan menghargai pasien dalam menerima informasi mengenai kondisi kesehatannya. Berdasar informasi tersebut maka pasien dan keluarganya dapat menentukan pilihan yang tepat apa yang akan dihadapinya (patient preferences and patient values). Harus diingat bahwa pemberian informasi yang tidak lengkap pada pasien baik disengaja maupun tidak disengaja cenderung menjadi awal dari sebuah sengketa medik. ${ }^{4}$

\section{Kegagalan diagnosis dan terapi}

Kegagalan diagnosis yang sering terjadi dan menyebabkan laporan kelalaian medik baik kepada pihak profesi maupun kepolisian di bidang kardiovaskular hingga saat ini ialah kegagalan diagnosis infark miokard. Walaupun penyebab kematian pasien pada kegagalan diagnosis infark miokard diakibatkan oleh penyakitnya sendiri, namun kegagalan seorang dokter untuk mendiagnosis akan menyebabkan hilangnya kesempatan bagi pasien untuk memperoleh pengobatan yang mungkin dapat merubah hasil akhir dari perjalanan penyakit saat itu. Contoh gugatan dugaan kelalaian medik pada kegagalan diagnosis pasien dengan infark miokard dapat dilihat pada kasus yang dipulangkan dari rawat inap di rumah sakit, yang kemudian meninggal sehari atau beberapa hari setelah dipulangkan. ${ }^{5}$ 
Kegagalan diagnosis infark miokard tidak selalu terjadi akibat suatu kelalaian medik. Tingkat kesulitan diagnosis infark miokard amat bervariasi. Pasien tidak selalu mengalami gejala klasik. Beberapa penyakit juga dapat memberikan gejala yang mirip dengan infark miokard. Pasien yang tidak memiliki faktor predisposisi sekalipun tidak artinya terlepas dari kemungkinan mengalami infark miokard. Pemeriksaan EKG dan enzim jantung juga dapat menunjukkan parameter negatif pada jam-jam awal terjadinya serangan. Seorang dokter spesialis atau spesialis konsultan jantung dan pembuluh darah tidak dengan mudah dapat diputuskan telah melakukan kelalaian medik ketika gagal mendiagnosis, terutama pada kasus dengan gejala tidak khas. $^{5}$

Kegagalan diagnosis dan terapi penyakit lain di bidang jantung dan pembuluh darah lain juga menganut prinsip yang sama dengan paparan mengenai kasus infark miokard di atas. Penggunaan Tissue Plasminogen Activator (tPA) pada kasus bencana vaskular yang tidak memberi hasil sesuai harapan atau prosedur CABG dan PCI yang menimbulkan komplikasi berat merupakan ranah-ranah dimana pasien kemungkinan besar bersengketa dengan dokternya. Tindakan yang mengikuti standar profesi, bidang kompetensi, dan standar prosedur operasi, akan membantu dokter dalam meletakkan posisinya dengan tepat pada suatu kasus sengketa medik. ${ }^{5}$

\section{PRINSIP UNTUK MENGURANGI RESIKO HUKUM}

\section{Rekam medik}

Pencatatan yang teliti untuk setiap data yang diperoleh dari pemeriksaan dan tindakan kedokteran di rekam medik merupakan benteng utama untuk membuktikan bahwa pelayanan kesehatan yang dilakukan telah memenuhi standar yang ditetapkan. Melaksanakan pengelolaan rekam medik yang baik akan dengan efektif menyediakan alat bantu untuk pembuktian bagi penyedia layanan kesehatan. Walau terkesan sederhana, namun problem pencatatan rekam medik merupakan problem yang ditemui di hampir setiap pusat layanan kesehatan di Indonesia, baik milik pemerintah maupun swasta. ${ }^{7}$

Rekam medik yang baik akan menggambarkan dengan jelas perjalanan penyakit, pemeriksaan yang telah dilakukan, dan tata laksana yang dipilih serta direncanakan. Rekam medis dapat berfungsi sebagai alat bukti dalam suatu masalah hukum, dan dapat dibuka dalam bentuk visum et repertum, keterangan ahli, keterangan saksi, atau ringkasan medik. Pembukaan rekam medik dalam bentuk tertulis hanya dilakukan bila ada permintaan tertulis dari pasien atau dari pihak yang berwenang. Harus diingat, dalam pengelolaan rekam medik, berkas rekam medik tidak dapat diserahkan kepada pihak di luar penyelenggara pelayanan kesehatan, kecuali atas dasar perintah pengadilan atau dalam sidang pengadilan.,

Merubah atau merevisi data medik pasien yang tersimpan dalam rekam medik, harus melalui tata aturan yang tepat. Bagian rekam medik yang direvisi tidak boleh dihilangkan, namun sebaliknya harus tetap terbaca, walau diberi tanda bahwa bagian tersebut mengalami koreksi. Menghilangkan bagian yang direvisi cenderung menimbulkan pendapat bahwa ada sesuatu yang salah terjadi saat pelaksanaan pelayanan kesehatan, dan justru dapat memicu timbulnya dugaan kelalaian medis. ${ }^{6}$

Pemusnahan rekam medik harus mengacu pada peraturan menteri kesehatan nomor 269/MENKES/PER/III/2008, yaitu 5 tahun sejak pasien berkunjung terakhir ke rumah sakit, dengan menyimpan ringkasan rekam medik dan persetujuan/penolakan tindakan medik selama 10 tahun. Pada fasilitas kesehatan bukan rumah sakit, rekam medik harus disimpan selama 2 tahun sebelum dimusnahkan. ${ }^{6}$

\section{Persetujuan dan penolakan tindakan medik (Informed consent)}

Pada banyak tindakan medik di bidang jantung dan pembuluh darah, pilihan tata 
laksana penyakit untuk pasien akan berdampak amat besar pada kualitas hidup pasien. Pasien dan keluarganya harus dikondisikan agar dapat memberikan informed consent atau menolak tindakan medis setelah memahami fakta medis yang relevan, implikasinya dan dampak pilihannya ke depan. Informed consent ini merupakan upaya untuk memberikan hak pasien dan keluarga dalam menentukan hidupnya atau keluarga dekatnya. Pemberian kesempatan menentukan ini menjadi tanggung jawab moral dan hukum penyedia layanan kesehatan. ${ }^{4}$

Persetujuan tindakan medik oleh pasien dapat disampaikan secara tersirat (implied), maupun diekspresikan secara lisan atau tertulis. Tidak semua tindakan kedokteran memerlukan persetujuan tindakan medik yang tertulis. Konsil Kedokteran Indonesia mengatur bahwa persetujuan tindakan medik tertulis diperlukan bila: ${ }^{8}$

- Tindakan terapeutik bersifat kompleks atau menyangkut risiko atau efek samping yang bermakna.

- Tindakan kedokteran tersebut bukan dalam rangka terapi.

- Tindakan kedokteran tersebut memiliki dampak yang bermakna bagi kedudukan kepegawaian atau kehidupan pribadi dan sosial pasien.

- Tindakan yang dilakukan merupakan bagian dari suatu penelitian.

Pada pemberian persetujuan atau penolakan tindakan medik secara tertulis, pasien diminta menandatangani 2 formulir, yaitu formulir dokumentasi pemberian informasi dan formulir persetujuan/ penolakan tindakan kedokteran. ${ }^{8}$

Informed consent yang telah ditanda tangani tidak berarti memberi imunitas bagi dokter terhadap laporan ketidakpuasan, kelalaian medis, maupun problem medikolegal yang lain. Namun dengan dilaksanakannya proses informed consent yang baik, terbentuk suatu keseimbangan beban tanggung jawab antara pasien dan dokter. Bila dokter telah melakukan tindakan sesuai kewenangan klinis, dan standar prosedur yang ada, maka dokter tidak dapat dituntut atau digugat untuk suatu kejadian tidak diinginkan yang tidak diduga atau tidak terhindarkan. ${ }^{8}$

\section{Kehati-hatian}

Kehati-hatian dalam mendiagnosis dan menentukan tata laksana harus selalu ada di benak dokter dalam menangani setiap kasus di bidang jantung dan pembuluh darah. Pelaksanaan Jaminan Sosial Nasional Bidang Kesehatan yang tidak dibarengi dengan pelaksanaan sistem rujukan yang baik menyebabkan menumpuknya pasien di institusi pelayanan kesehatan sekunder dan tersier. Jumlah pasien yang besar, jam pelayanan yang panjang, dan adanya permasalahan lain dapat menurunkan kewaspadaan dan kehati-hatian dokter. ${ }^{5}$

Rumah sakit yang menjadi wahana program pendidikan dokter spesialis-1 memiliki masalah khas dengan hadirnya dokter PPDS. Pengawasan yang menurun terhadap peserta didik dapat mengakibatkan kejadian medik yang tidak diinginkan, yang dapat berujung pada masalah etik, disiplin, dan hukum. Rumah sakit juga perlu melaksanakan proses kredensial dengan baik dan objektif agar masyarakat memperoleh dokter-dokter ahli yang benarbenar mampu dalam pelayanan di bidang jantung dan pembuluh darah. ${ }^{7}$

Setiap dokter diharapkan menyikapi dengan serius persyaratan kualifikasi personal dalam kriteria pemberian kewenangan klinis yang ditetapkan oleh Kementerian Kesehatan RI. Organisasi profesi atau pihak penyelenggara layanan kesehatan diharapkan mampu membantu dokter memenuhi kualifikasi ini agar dalam memberi layanan dokter dapat terlindungi dan keselamatan pasien dapat terjaga. ${ }^{8}$

\section{SIMPULAN}

Pelayanan di bidang Kardiologi di Indonesia merupakan pelayanan kesehatan yang amat dibutuhkan, dan hingga saat ini perbandingan dokter ahli dengan jumlah 
penduduk Indonesia masih amat timpang. Pengembangan ilmu, pusat pendidikan, dan dukungan pemerintah baik pusat maupun daerah dalam pendanaan peserta didik di bidang terkait harus menjadi prioritas ke depan.

Pelayanan kesehatan di bidang Kardiologi merupakan pelayanan kesehatan yang berisiko, namun memiliki angka laporan ketidakpuasan layanan yang rendah di masyarakat. Selain komponen pelayanan medik yang baik, seorang dokter ahli diharapkan mampu membina komunikasi dokter-pasien secara efektif, melaksanakan pedoman praktik kedokteran yang baik, termasuk di dalamnya melaksanakan pengelolaan rekam medik dan informed consent dengan tepat. Kehati-hatian harus selalu ada dalam setiap pengelolaan kasus, namun harus dijaga agar tidak berevolusi menjadi "defensive medicine" yang merugikan pasien.

\section{DAFTAR PUSTAKA}

1. Romdoni R. Pidato Sambutan Ketua PP PERKI pada Pembukaan The 22nd ASMIHA. 22nd Annual Scientific Meeting of Indonesian Heart Association (ASMIHA). Jakarta: Hotel Ritz Carlton; 5-7 April 2013.
2. Kementerian Kesehatan RI. Profil kesehatan Indonesia tahun 2012 [homepage on the Internet]. 2012 [cited 2013 Sep 04]. Available from: http://www.depkes.go.id/ downloads/Profil_Kesehatan_2012(4Se pt2013).pdf.

3. Sampurna B. Etika kedokteran Indonesia dan penanganan pelanggaran etika di Indonesia. Lokakarya Peningkatan Peran Kedokteran Forensik dalam Penegakan Hukum di Indonesia. Jakarta: Aula FKUI; 29 Maret 2005.

4. Undang-undang nomor 36 tahun 2009 tentang Kesehatan.

5. Abbot R, Cohen M. Medico-legal issues in cardiology. Cadiology in Review. 2013; 21(5):222-8.

6. Peraturan Menteri Kesehatan Republik Indonesia nomor 269/MENKES/PER/ III/2008 tentang rekam medis.

7. Peraturan Menteri Kesehatan Republik Indonesia nomor 36 tahun 2012 tentang rahasia kedokteran.

8. Rafly A, Sampurna B, (editors). Manual Persetujuan Tindakan Kedokteran. Jakarta: Konsil Kedokteran Indonesia, 2006; p.16-20.

9. Peraturan Menteri Kesehatan Republik Indonesia nomor 755/MENKES/PER/ IV/2011 tentang penyelenggaraan komite medik di rumah sakit. 